\title{
How To Interpret The Balance of Payments Accounts
}

The Balance of Payments Accounts is a double entry record of real and financial transactions between U.S. and foreign residents. Because it is based on double entry bookkeeping principles, the balance of payments always balances in the sense that receipts always equal payments. The double entry nature of the Balance of Payments Accounts is shown on the left-hand side of the accompanying table. This strictly accounting balance must not be confused, however, with a meaningful economic balance, because the economic behavior underlying some of these transactions may not be sustainable. For example, the receipt of $\$ 1.2$ billion in 1967 from the sale of the U.S. gold stock (IV.3.a) cal only continue as long as our gold stock lasts. There are two officially accepted measures of our economic Balance of Payments, the Liquidity Balance and the Official Settlements Balance, which are shown on the right-hand side of the table.

To understand the bookkeeping aspect, it is convenient to divide the Balance of Payments Accounts into four categories: Goods and Services, Private Capital, Government, and Other. These accounts are, of course, linked to one another; an export could be financed by a private bank loan, by a Covernment grant, or by a private gift.

I. Goods and Services: Merchandise exports and imports are a measure of physical goods which cross national boundaries. Service exports and imports measure purchases and sales of services by U.S. residents to foreign residents. Sales of military equipment are included in service exports, and U.S. military purchases abroad are included in service imports (I.2.a). Investment income from the large volume of U.S. direct and portfolio investment abroad is the largest surplus item in the service category (I.2.b). Next to military, travel is the largest deficit item in the Goods and Services category (I.2.c).

II. Private Capital: For long-term capital, this records all changes in U.S. private assets and liabilities to foreigners. Net increases in U.S. assets are measured as payments of dollars abroad, and net increases in U.S. liabilities are measured as receipts of U.S. dollars from abroad. Direct investment (II.1.a) by Americans abroad is much larger than direct investment by foreigners in the United States. However, portfolio investment (II.1.b) is abont evenly divided. For short-term capital, payments represent changes in all private U.S. assets, while receipts represent only changes in non-bank short-term liabilities. Changes in U.S, bank short-term liabilities are listed under IV.4 along with short-term liabilities of U.S. official monetary institutions.

III. Government: Gross outflow of loans, grants, and transfers for the Government were $\$ 5.6$ billion, and the net outlow was $\$ 4.2$ billion in 1967. A large share of
Government loans and grants is tied to purchases in the United States. To the extent that tied purchases would not have been made without the Government loan or grant, this results in an increase in exports of U.S. Goods and Services. Thus, the $\$ 4.2$ billion deficit somewhat overstates the Government's real impact on the overall Balance of Payments deficit.

IV. Other: Private Transfers represents gifts and similar payments by American residents to foreign residents. Errors and $O_{\text {missions is the statistical discrepancy between }}$ all specifically identifiable receipts and payments. It is believed to be largely umecordec short-term capital movements. Changes in U.S. Reserve Assets represent official transactions of the U.S. Government with foreign governments and the International Monetary Fund. Changes in U.S. Liquid Liabilities represent increased foreign holdings of liquid dollar liabilities of U.S. private and official monetary institutions (Banks, the U.S. Treasury and the Federal Reserve).

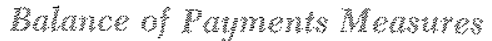

Two economic measures of the balance of payments are represented in the table. The Net Balance column shows the source and overall size of the deficit or surplus, while the Financing column shows how the deficit is financed or the surplus disposed.

The major difference between these two measures is the way foreign holdings of U.S. bank and Treasury liabilithes are handled. The underlying assumption about economic behavior in Liquidity Balance is that all foreign holdings of dollar liabilities which mature in one year or less (Liquid Liabilities) are a real claim on the U.S. gold stock. As such, the Liquidity Balance measures the actual decline in the U.S. gold stock and other reserve assets of the U.S. Government and increases in all U.S. liquid liabilities to foreigners.

The underlying economic rationale of the Official Settlements Balance is that only foreign official holdings of dollars represent a real clam on the gold stock. Foreign private holders and international organizations have a demand for dollar balances as an international currency in the same way as they may have a demand for any U.S. services. Thus, an increase in foreign private holdings of dollars is treated in a manner similar to that of a capital inflow; i.e, included in the Net Balance column rather than in the Financing column. The Official Settlements Balance measures changes in U.S. reserve assets, and changes in foreign official holdings of dollars both liquid and non-liquid. Thus, long term U.S. bank liabilities of $\$ .8$ billion and U.S. Treasury liabilities of $\$ .5$ billion purchased by foreign governments are in the Financing column. 
U. S. BALANCE OF PAYMENTS, 1967

(In Billions of Dollars)

\begin{tabular}{|c|c|c|c|c|c|c|c|c|}
\hline & \multirow{4}{*}{ Transactions } & \multirow{3}{*}{\multicolumn{3}{|c|}{ Balance of Payments Accounts }} & \multicolumn{4}{|c|}{ Balance of Payments Measures } \\
\hline & & & & & \multicolumn{2}{|c|}{ Liquidify Balance } & \multicolumn{2}{|c|}{ Official Settlements Balance } \\
\hline & & & & & \multirow{2}{*}{ Net Balance } & \multirow{2}{*}{$\begin{array}{c}\text { Financing } \\
\text { of Nef Balance }\end{array}$} & \multirow{2}{*}{ Nef Balance } & \multirow{2}{*}{$\begin{array}{c}\text { Financing } \\
\text { of Net Balance }\end{array}$} \\
\hline & & Receipts & Payments & Balance & & & & \\
\hline \multirow{7}{*}{ 1. } & Goods and Services......... & 45.8 & 41.0 & +4.8 & +4.8 & $\cdots$ & +4.8 & $\cdots$ \\
\hline & 1. Mdse. Trade (goods)...... & 30.5 & 27.0 & +3.5 & $\ldots$ & $\cdots$ & $\cdots$ & $\cdots$ \\
\hline & 2. Services............ & 15.3 & 14.0 & +1.3 & $\cdots$ & $\cdots$ & $\cdots$ & $\cdots$ \\
\hline & a. Military $\ldots \ldots \ldots \ldots \ldots$ & 1.2 & 4.3 & -3.1 & $\cdots$ & $\cdots$ & $\cdots$ & $\ldots$ \\
\hline & b. Investment Income.......... & 6.9 & 2.3 & +4.6 & $\cdots$ & $\cdots$ & $\cdots$ & $\cdots$ \\
\hline & c. Travel. . . . . $\ldots \ldots \ldots$ & 1.7 & 3.2 & -1.5 & $\cdots$ & $\cdots$ & $\cdots$ & $\cdots$ \\
\hline & d. Other $\ldots \ldots \ldots \ldots \ldots$. & 5.5 & 4.2 & +1.3 & $\cdots$ & $\cdots$ & $\cdots$ & $\cdots$ \\
\hline \multirow[t]{6}{*}{ II. } & Private Capital. ........... & 2.7 & 5.5 & -2.8 & -2.8 & $\ldots$ & $\ldots$ & $\ldots$ \\
\hline & 1. Long term............. & 2.3 & 4.3 & -2.0 & $\ldots$ & $\ldots$ & $\cdots$ & $\ldots$ \\
\hline & a. Direct Investment. . .......... & .2 & 3.0 & -2.8 & $\cdots$ & $\ldots$ & -2.8 & $\ldots$ \\
\hline & b. Portfolio lnvestment.......... & 1.0 & 1.3 & $\begin{array}{l}-.3 \\
0\end{array}$ & $\ldots$ & $\cdots$ & -.3 & $\cdots$ \\
\hline & c. Bank and Other Loons (Net).... & 1.1 & .0 & +1.1 & $\cdots$ & $\cdots$ & +.3 & +.8 \\
\hline & 2. Short term........... & .4 & 1.2 & -.8 & $\cdots$ & $\cdots$ & -.8 & $\ldots$ \\
\hline \multirow{3}{*}{ III. } & Government (non-military)..... & 1.4 & 5.6 & -4.2 & -4.2 & $\ldots$ & $\ldots+$ & $\ldots$ \\
\hline & 1. Loans................. & 1.4 & 3.4 & -2.0 & $\ldots$ & $\ldots$ & -2.5 & +.5 \\
\hline & 2. Grants and Transfers....... & $\cdots$ & 2.2 & -2.2 & $\cdots$ & $\cdots$ & 2.2 & $\cdots$ \\
\hline \multirow{14}{*}{ IV. } & Other................ & & & & & & & \\
\hline & 1. Private Transfers........... & $\ldots$ & .8 & -.8 & -.8 & $\ldots$ & -.8 & $\ldots$ \\
\hline & 2. Errors and Omissions......... & $\ldots$ & .5 & -.5 & -.5 & $\ldots$ & -.5 & $\cdots$ \\
\hline & 3. Changes in U.S. Reserve Assets & 1.2 & 1.1 & +.1 & $\ldots$ & $+\quad .1$ & $\ldots$ & +.1 \\
\hline & a. Gold loutflow is receiptl . . . . . & 1.2 & $\cdots$ & +1.2 & $\ldots$ & $\cdots$ & $\ldots$ & $\cdots$ \\
\hline & b. Convertible Currencies ........ & $\ldots$ & 1.0 & -1.0 & $\cdots+$ & $+\cdots$ & $\cdots$ & $\ldots$ \\
\hline & c. I MF Gold Tranche Position.... & $\cdots$ & .1 & -.1 & $\cdots$ & $\cdots$ & $\ldots$ & $\cdots$ \\
\hline & 4. Changes in U.S. Liquid & & & & & & & \\
\hline & Liabilities. . . . . . . . . . . & 3.7 & .2 & +3.5 & $\cdots$ & +3.5 & $\cdots$ & $\cdots$ \\
\hline & a. Foreign Official Holders....... & 2.0 & $\ldots$ & +2.0 & $\ldots$ & $\cdots$ & $\cdots$ & +2.0 \\
\hline & b. Foreign Prvt. Holders. . . . . . . & 1.7 & $\cdots$ & +1.7 & $\cdots$ & $\cdots$ & +1.7 & $\cdots$ \\
\hline & c. Int'l. Organizations & & & & & & & \\
\hline & other than $f M F \ldots \ldots \ldots \ldots$ & $\cdots$ & .2 & -.2 & $\cdots$ & $\cdots$ & -.2 & $\cdots$ \\
\hline & Total. . . . . . . . . . . & 54.8 & 54.8 & .0 & $-3.6 *$ & +3.6 & $-3.4^{*}$ & +3.4 \\
\hline
\end{tabular}

